\title{
Maternal Experiences in Caring for Their Neonates in Two Communities around Kupang, West Timor: A Qualitative Study
}

\section{Maria Margaretha Ulemadja Wedho}

Department of Health, East Nusa Tenggara, Indonesia

*Corresponding author: Wedho MMU, Department of Health, East Nusa Tenggara, Indonesia, E-mail: Mariawedho@yahoo.com

Received date: September 19, 2017; Accepted date: October 16, 2017; Published date: October 20, 2017

Copyright: @2017 Wedho MMU. This is an open-access article distributed under the terms of the Creative Commons Attribution License, which permits unrestricted use, distribution, and reproduction in any medium, provided the original author and source are credited.

\begin{abstract}
Background: The Health development targets are to accelerate the decrease in Infant Mortality Rate (IMR) and Maternal Mortality Rate (MMR).
\end{abstract}

Aim: The purpose of this study was to explore women's experiences of taking care of their infant/neonates (age 0-28 days) in two communities around Kupang. West Timor Desa Bipolo Kecamatan Sulamu and Kelurahan Sikumana Kota Kupang East Nusa Tenggara Indonesia.

Method: Qualitative research with case study approach was used to assess women's experience in taking care of neonates. Five women with neonates were chosen as population and purposive sampling was conducted to select the respondents. Data were collected by the way of in-depth interviews with the mother. Moreover, there were 3 stages of data analysis consisting of: data reduction, display data, and conclusion drawing/verification.

Results: Three themes related to women's experiences in taking care of neonates were identified. Those are: neonatal check-up or visitation, nutrition for six post neonate women, and the level of mother's knowledge. The result of this study showed that not only respondents have never been visited by health worker based on the Government standard in NTT Province, but also they have never been educated on how to take care of and to feed their neonates well.

Recommendation: Further study should be conducted by health care worker or government in this case the Provincial and District Health Office to motivate the mother and family to compliance to government regulation standard to take care of neonatal. Health workers are expected to design the guidelines and counselling to decrease infant mortality rate in the community through education during the prenatal period. Heads of the village are expected to insist that the community especially pregnant women to visit health facilities at least 3 times during the neonatal period. The health workers are expected to visit families with neonates at least 3 times in the first week of neonatal life.

Keywords: Women experiences; Infants; Neonates; Care

\section{Introduction}

One of the Millennium Development Goals (MDGs) in 2015 was to reduce the child mortality rate. Infant mortality rate worldwide has decline sharply from an estimated rate of 63 deaths per 1000 live births in 1990 to 32 deaths per 1000 live births in 2015. Indicators of children mortality rate in Indonesia are neonatal mortality rate; Infant Mortality Rate, and under five mortality Rate. Indonesian Government emphasizes on decreasing neonatal age 0-28 days mortality rate because $59 \%$ of infant death is caused by neonatal mortality rate [1]. Health Survey of Demography2012showed that neonatal mortality rate was 19 per 1.000 live births; it was equal with Neonatal Mortality Rate in 2007. Meanwhile, based on Health survey in 2002-2003, Neonatal Mortality Rate was 20 per 1.000 live births and was only decrease 1 point when compared to the result of health survey of demography in 2012. Furthermore, the result of population census in 2015 showed that Infant Mortality Rate was 22-25 per 1.000 live birth means MDGs target to decrease until 23 per 1.000 live births has been achieved in Indonesia [1].
Infant mortality rate has also been declining in other Province all over Indonesia. In 1994 the infant mortality rate in Nusa Tenggara Timur (NTT) Province was 71 per 1,000 live births dropped successively to 60 per 1,000 live births in 1997; fell again to 59 per 1,000 live births between the year of 2002 to 2003 , and 57 per 1,000 live births in 2007 [2]. Based on population census in the year of 2010 infant mortality rate was dropped to 39 per 1,000 live births [3]. Meanwhile infant mortality rate in NTT fluctuates from 2011 to 2015. The number of cases in 2011 was 1272 out of 93.531 live births. This number of cases increased to 1350 per 97.131 live births in 2012, and 1367 cases out of 77525 live births in 2013. The infant mortality rate increased again from 1408 or 15 per 1000 live birth in 2014 to 1568 or 12 per 1000 live birth in 2015. Those data reflected that infant mortality rate in NTT is still high compare to other Province in Indonesia. Sumba Timur District was contributed the highest number of cases of infant mortality with 88 cases in 2014 followed by Kupang regency 43 cases in 2014, increased to 63 cases in 2015 [4]. It was the reason to choose Kupang regency as a sample in this study.

The two leading causes of infant mortality are prematurity and infection [5]. Causes of neonatal death in Indonesia are Asphyxia in 
0-6 days (37\%), prematurity (34\%), and sepsis (12\%) [2]. Neonatal is the most vulnerable age group that needs more attention.

Indonesian Government has put a lot of effort to decrease infant and maternal death. Several strategies that have been implemented by the Government are assisted delivery, neonatal visitation (0-28 days) by health workers at least 3 times and implemented early initiation of breastfeeding.

First neonatal visitation is done in 6 to 48 hours after birth; second is 3 to 7 days and last visitation is 8 to 28 days $[1,6]$. Based on decision of Minister of Health Number 1464/Menkes/Per/X/2010 articles 11 midwives are responsible to take care of neonatal (0-28 days). They are assigned to take care of normal newborn including prevent hypothermia, take $\mathrm{K}$ vitamin injection, cord care, take regular immunization, and facilities of early breast feeding $[1,6]$. Health care worker should visit neonatus if mother and family did not take the baby to the health centre. In reality, they lean to wait in health centre without any effort to visit the neonate that lead to lack of neonatal monitoring. Contrary with mother's opinion especially who are lack of knowledge about the benefit of neonatal visite. They think that healthy baby does not need to check their health status to health centre. In addition, this judgment is supported by the local customs that forbid them to bring out the baby before 40 days.

Zuraida [7] conducted the study about the factors related to neonatal visit in Public Health Centre of Lubuk Kilangan Padang to 56 mothers who had neonatal age more than 28 days and did neonatal visite. The result showed that $57.1 \%$ of respondent had knowledge deficit; $55.6 \%$ had negative attitude, and $55.4 \%$ of respondent had not met neonatal visitation goal. Statistical analysis showed that there was relationship between knowledge ( $\mathrm{p}$ value $=0.009)$, attitude $(\mathrm{p}$ value $=0.004)$, worked ( $p$ value $=0.000)$ with neonatal visit. She concluded that more than half of mothers who had lack of knowledge, attitude, and unemployed were the cause of poor neonatal visitation. Darmawan and Dewi [8] stated that there was significant relationship between mother knowledge and their attitude to take the neonatal to health centre. The result of the study showed that $50 \%$ of respondent who were less knowledgeable, never taken the baby to health centre call KN 1 (first visit), meanwhile fairly knowledge (93.5\%) and good knowledge (96.8\%) mother done neonatal visited 1 (KN 1) >1 time. These findings supported the research conducted by Mahmudah, et al. [9]. The result showed that the risk factors associated with the incidence of perinatal mortality in Batang was the mother's education $(\mathrm{p}=0.006, \mathrm{OR}=3.878)$; mother's knowledge $(\mathrm{p}=0.013, \mathrm{OR}=2.843)$; parity $(\mathrm{p}=0.016, \mathrm{OR}=2.988)$; low birth weight $(\mathrm{p}=0.001, \mathrm{OR}=7.570)$, asphyxia $(\mathrm{p}=0.001, \mathrm{OR}=2.270)$, and congenital abnormalities $(\mathrm{p}=0.003$, $\mathrm{OR}=2.205)$.

The causes of infant death can be reduced by increasing the provission of infant immunne colostrums in the breast milk through early initiation of breastfeeding. Therefore, maternal nutrition status during lactation contributes to successful breastfed. Exclusive breast milk should be given to the baby until age of 6 months. Mother should consume food contain of high nutrition in order to produce high quality of milk. However, most mothers did not successfully breastfed their infant. Irawati et al. [10] stated that nutrition status of maternal during lactation significant contribute to successful breastfeeding after controlling other factors such as food pattern and social economic factors. During lactation, the risk of thin mothers $(\mathrm{IMT}<18.5)$ to unsuccessful breastfeeding is 2.26-2.56 times compared to normal mothers (IMT $\geq 18.5-25.0$ ) with $\mathrm{RR}=2.26-2.56$. Therefore, mother should consume more high nutrition food to achieve successful breastfeeding.

The role of mother and family in taking care of infant are very essential in reducing newborn deaths. The family plays an important role in reducing or eliminating the risks of respiratory disorders, infections, hypothermia, and other factors that are known to cause death. The family especially the mother is the first person who is in close contact with the newborn, particularly when birth takes place at home. However, education, knowledge, and attitude of mother impede them to take the infant to health centre based on Government regulation namely neonatal visitation $(\mathrm{KN})$. These conditions are supported by local custom that prohibit them to bring out the baby before the age of 40 days.

This research was conducted to explore the mother's experiences in taking care of their new-born baby in the first 28 days of life in community of high infant mortality.

\section{Methods}

\section{Study design}

Qualitative research was used with case study design to explore mother's experiences in taking care of the infant in the first 28 days of life.

\section{Setting and participants}

This study was conducted in rural districts of Bipolo Sulamu Kupang Regency; and Sikumana village, Maulafa Kota Kupang from June to August 2015. The village was chosen because it was one of the villages in Kupang district that has a neonatal mortality rate in 2014 is high at 70 cases when compared with other districts like Kota Kupang were only 16 cases. Sikumana Sub-district was also chosen because it has a high infant mortality rate. Participants were selected by using non-random purposive sampling. Five postnatal women participated in this study. Inclusion criteria were postpartum women who had newborns aged 0-28 days at the time of the study with the following criteria: willing to become participants, able to read, write, and understand Indonesian.

\section{Data collection}

Participants were informed about the aim of the study and the interview process. Data were collected by interview. According to Esterberg [11] interview can be done by structured interview, semi structured interview, and unstructured interview. In this study structured interview was chosen because each respondent got the same question that has been designed by the researcher. The interviews were conducted in participants' houses. Open ended questions were conducted to elicit women experience in taking care of their neonates. The questions asked were as follows:

a. "Would you please tell me how you check your neonate health?"

b. Would you please describe the kind of food you ate to increase your milk production after giving birth?

c. Would you please tell me how you took care of your new-born such as breastfeeding, bathing, and taking care of the cord?

The interview was tape-recorded and lasted for 60 to $120 \mathrm{~min}$. During interview field notes were written to support the participants' 
statements and the data interpretation. The audio-recorded interviews were transcribed verbatim after each interview was completed.

\section{Analysis}

Data were analyzed using analysis of themes [12]. There were 3 stages of data analysis consisting of: data reduction, display data, and drawing conclusions/verification [12].

\section{Ethical consideration}

This research proposal was approved by the Ministry of Health Specialist team Poltekkes Kupang on December 2015 prior to data collection. All participants were informed about the aim of the study and the written inform consent was obtained before the interviews began.

\section{Results}

Five post-partum mothers agreed to participate in this study. Two participants lived in Timor; 2 lived in Rote Island and one from Manggarai-Flores. Their ages ranged from 20 to 33 years old. Four of the five mothers were Protestant, while one participant was Catholic. Two participants graduated from high school, one from lower secondary school, and two from primary school. Four participants were housewives, and one was a farmer. All of the women were married. Two of the husbands were farmers and the others a driver, a taxi driver, and unemployed. Only one participant was a first time mother. For two participants this was their second baby; one had given birth 4 times, and one 6 times. Two participants live in the villages of Bipolo Kupang and the others lived in Sikumana. Three women delivered in their house helped by a traditional birth attendant or a shaman; meanwhile one delivered in the hospital and one in a health centre helped by midwife.

Thematic analysis was obtained based on mothers' experience in taking care of their neonates. Several serious problem were identified including: neonates not being taken to health facilities 3 times during the first 28 days of life as recommended by government; inadequate food consumption by the mother during the postnatal period led to poor quality of milk for the infant; improper care of the umbilical stump; to infection; and mothers' lack of knowledge about basic nutrition. Based on the analysis of these data then three themes were set: 1) Neonatal Check-up or visitation; 2) Quality of milk; 3) Mothers' knowledge. Each theme will be discussed with emphasized on the experiences of the participants in taking care of their babies. Although discussed separately, the themes were interrelated.

\section{Infant health check and neonatal visits}

The interview began with a question: "Would you please tell me how you check your baby's health?" The participant had little understanding of the value of taking their babies to the health centre for check-up. Most of them said that as long as the babies were healthy, it was not necessary to take them to the health center for examination. One participant said that she never checked the infant condition even though the baby was unhealthy. It was because of their customs and habit. She said...

......"My son had a cold for 2 days and he was not taken to the health center. My parents told me that I was not allowed to leave the house for 40 days after the birth of the baby. This is our belief and customs that we cannot go against"...
One participant who gave birth at home explained that since the first child she used to deliver at home helping by a traditional birth attended. However, in this current birth, her husband reported to health care worker after delivering the baby. The nurse visited me and the new-born once. Moreover, the participant had never taken the baby to the health centre. She said ...

... "The day after giving birth, my husband contacted the nurse in the health center so they visited me and gave me a drug related add blood and yellow tablet. The nurse also gave $\mathrm{HbO}$ immunization injections in the thigh of baby"...

\section{The quality of milk}

Maternal nutrition in order to increase the quality of milk for the baby is an essential aspect explored in this interview. The question asked was: "Would you please tell describe the kinds of food you ate to increase your milk production after giving birth?" All participants said that they did not really care about the quality of food during the breast feeding period. They ate only rice and vegetable during the post-natal period. Food rich in protein and fat, such as fish, meat and eggs, were rarely consumed. The participants believed that eating only vegetables could increase their milk production. Meanwhile food such as tofu, tempeh, fish and meat did not increase the excretion of breast milk. In addition, in their belief and customs the post-natal women were not recommended to eat fish as it was said to lead to the breast milk smelling fishy. This was expressed by one participant.

..... "I eat rice porridge that was instructed by the doctor. I did not eat fish because it was taught from my mother that after giving birth, we should not eat fish for 40 days because it would cause a fishy smell in the breast milk. Sometimes I ate chicory only if there was a vegetable vendor who passes through approximately 2-3 times a week. I rarely ate side dishes only there were any new eggs eaten. Legumes such as peanuts, green beans were taken if available. In general, I ate porridge without salt because it was prohibited"...

All participants said that they did not know about nutrition for the post-natal women and infant. One participant said......

......I never received any counselling about important food for nursing mothers or infants. I learned from the experience of taking care of another child. In my family there were no restrictions so I could eat vegetables from our own gardens. The lack of other side is sometimes due to lack of funds as a consequent of my unemployed husband".........

\section{Level of mothers' knowledge}

"Would you please tell me how you took care of your new-born such as breastfeeding, bathing, and taking care of the cord? It was the questions to get information about the participants' method of taking care of their babies. Basically, they got the knowledge of caring for the baby from their parents. They seemed to lack of knowledge about handling the new-born such as cord care, and breastfeeding. One participant said....

.... "After bathing the baby, I took care of the umbilical cord using the milk powder mixed and applied to the umbilical cord".......

\section{Another participant said...}

....'I used to clean the umbilical cord with cotton sticks directly after bathing the baby"... 
Usually, the babies will be breast feed every 1 to $2 \mathrm{~h}$ or when the baby cried. The mother used to carry the baby during the day in order to breastfeed directly to calm them. Other participants revealed that when the baby did not want to breastfeed she searched for her own alternative without checking with a doctor or a midwife. She said...

...."I wake up at 05:30 in the morning to express milk into a bottle, and I gave it to my baby. My baby refused to suck from the nipple since birth"...

All participants said that the method they used to taking care of the infant derived from parents or generation to generation. They followed without understanding and rationalization against them. It was surely understood that the pattern of neonatal infant care used by participants who were not in accordance with the standard also caused by lack of knowledge of the mothers and their families. One participant said. ..

........"I ate porridge or rice mushy, did not eat fish because it was forbidden. Eat vegetables chicory sometimes only if there was a vegetable vendor through approximately 2-3 times a week. I rarely ate side dishes such as meat, fish, or eggs. If I had some legumes such as peanuts, green beans, I would consume it. But in general I ate porridge without salt because it was banned by parents"...

Those experiences were an overview of the culture, customs, and more of society in several areas in the province that did not comply with the applicable health standard.

After bathing the baby, I took care of the umbilical cord using the milk powder mixed and applied to the umbilical cord" .......

Another participant said...

...."I used to clean the umbilical cord with cotton sticks directly after bathing the baby"....

\section{Discussion}

According to SKDI data [13] Infant Mortality Rate (IMR) and under five years child mortality rate have been decreased significantly from 1990 to 2015 become 32 per 1,000 live birth. Neonatal death aged 0-28 days constituted of $2 / 3$ infant mortality rate, meanwhile perinatal death (infant aged 0-7 days) comprised of $2 / 3$ from neonatal death. Actually, contribution of neonatal mortality rate to infant and children below five years mortality rate is very significantly. Raharni et al. [14] reported that most of early neonatal death (0-7 days) 144 cases (88.6\%), half of them were early neonatal death. The rest of it was late neonatal death $11.45 \%$.

Infant mortality rate is higher during neonatal period [5]. SDKI (Survey Demography and Indonesian health) 2007 [15] showed that Cases of Neonatal mortality rate was $78.5 \%$ during first week of life (0-6 days). Therefore, Department of health determined that every new-born should have their condition checked by a qualified health worker as soon as possible twice in the first week. The aim of this intervention is to early detect of danger signs and symptoms in order to prevent neonatal death. Neonatal check-ups on a regular basis are an important part of the overall continuum of neonatal care. Neonatal health check-ups can be done both by taking the baby to the health centre by visiting them at home. Mother and family will be informed about the method of taking care of the infant including: a) identifying diseases faced by neonates, danger signs of disease, immunization status; b) dealing with breastfeeding problems; c) determining problems or other complaints; $d$ ) measuring and providing treatment if necessary; e) referring them and giving the action pre-referral, counselling for mothers, and giving follow-up services [16-18].

In this study, a baby with 2 days cold was not treated because of the local custom that prohibited mother and the baby to get out from house for 40 days after childbirth. According to the policy of the Ministry of Health the baby who getting cold should be cleaned off her airway mucus by using a suction device, and administering oxygen by nasal catheter [16-18]. Mothers who are not aware of the baby's condition may harm the baby. Infants can be exposed to various diseases such as Infection, Sepsis, Tetanus, Pneumonia, and Diarrhea [16-18]. Stoll (1995) stated that Indonesia in the year of 1995 included in the 12 countries with high estimated cases of neonatal infection. Those diseases have the largest contribution to infant mortality rate as much as $57.1 \%$ [13]. Factors that contribute to neonatal infections are mostly by lack of caring. The key to overcome this problem were Tetanus Toxoid (TT) immunization, apply clean delivery and proper cord care [16-18]. Using or applying liquid or any material into the umbilical stump are prohibited, however in the case of infection aseptic technic must be applied by using alcohol or povidone iodine [16-18]. This study showed that this was not being followed. The result showed that responden applied milk powder mixed to the umbilical cord and cleaned directly the umbilical cord with cotton sticks fter bathing the baby.

Darmawan and Dewi [8] in their study about the correlation between mother knowledge and husband's support in neonates visite 1 (KN 1) in Health Centre of Pasirlangu West Bandung stated that knowledge and attitude of mother were two essential factors that influence the method they conducted to take care of neonate. The result of their study indicated that half of respondent (50\%) who had knowledge deficit never took the neonate to health centre. Meanwhile, 93.5\% respondent who had fairly knowledge and 96.8\% respondent had good knowledge brought the neonate to health centre $(\mathrm{KN} \mathrm{1})>1$ time. Statistical examination showed that there were significantly relationship between mother knowledge and their attitude to take the neonate to health centre. These findings supported the research conducted by Zuraida [7]. She stated that knowledge, attitude and job of the mother can influence noncompliance of neonatal visit. She pointed out in her result that there were statistical significantly between knowledge ( $p$ value $=0.009)$, attitude $(p$ value $=0.004)$, worked ( $\mathrm{p}$ value $=0.000$ ) with neonatal visited. Therefore, mothers' education, knowledge, and attitude are the main factors that influence the successful of Government program to decrease neonatal mortality rate, beside competence of health worker to handle all the condition in the community.

Ministry of Health has decided that newborn baby should be cared by midwife. Newborn should be prevented from incidence of hypothermia. In addition, midwife is responsible to taking vitamin $\mathrm{K}$ injection to preventing bleeding, giving regulation immunization such as $\mathrm{HbO}$ injection in the age of 0-7 days, providing health education about cord caring, and initiating of early breast feeding $[1,6]$. Based on decision of Minister of Health Number 1464/Menkes/Per/X/2010 articles 11 midwife should visit neonatus based on Governmen regulation if mother and family won't take the baby to the health centre. The result of this study showed that midwife tend to wait at health centre without any effort to visit the neonate. Lack of neonatal visited on primary health programs is a contrary to NTT provincial governments' program to reduce infant mortality rate. The technical manual on sharply reducing infant mortality in NTT province issued by the provincial health bureau stated that health workers will conduct 
several visits to neonatal; such as visit on the day below 7 days (or less) as much as three times especially on first 6-48 hours 1 times, on day 3-7 one time and on day 8-28 once $[6,19]$.

Participants' experienced showed that the government program was not running well and were not properly implemented. In reality, health workers did not do home visits and postpartum mothers also did not bring their babies to a health centre. This was contrary to the opinion of Bang et al. [20] in his research on "Reduce Incidence of Neonatal morbidities: Effect of Home-Based Neonatal Care in Rural Gadchiroli, India in 1995 and 1998". He stated that the intervention could reduce neonatal morbidity. Bang explained further that the effects of neonatal care at home against neonatal morbidity with the intervention of field personnel who were very well trained. In the first year of this study, trained health workers carried out home visits to observe the activities of the mother to taking care of her baby. In the second years they helped mothers to take care of healthy and sick new-borns; in the third years they provided health education to the mother and family member. As a result of this intervention: home care and health education successfully reduced the incidence of neonatal morbidity rate close to $50 \%$ and also the costs.

Karim et al. [21] conducted a study about the effects of intervention to change health practice for mothers and new-borns in Ethiopia. They established a national program to expand health programs called Health Extension Program (HEP) include interventions to save newborn-based community to improve the health of new-borns. Implementation of the save children program consist of: helping clean delivery practices; cleaning cord care, giving thermal care, extra caring for LBW, and exclusive breastfeeding early. The results showed that an increase in the score, OR antenatal care increased acceptance of 1:13 (95\% CI 1:03 to 1:23); OR increased birth preparation time (1:19 to $1: 44)$; OR receive post-natal care increased by 1.60 times (1.34-1.91); and OR start breastfeeding immediately after birth increased by $1: 10$ time (1:02 to $1: 20)$.

The results of those two studies showed that nursing interventions such as home visit is very important. In this research, participant did not take the baby to health centre even though they were sick because of local belief customs. Health workers who have already known the local customs were expected to visit the infant and their mothers regularly based on a standard guideline, so the preventive measures of morbidity and mortality can be implemented earlier.

Other Government program to decrease infant death is early initiation of breastfeeding and Exclusive Breastfed. Minister of Health in her regulation number 450/2004 about Exclusive Breastfed insisted to all health worker to support and campaign about providing only Exclusive Breastfed to the baby during 6 month [22]. Mother and family should be provided counselling about the important of nutrition because successful breastfeed during lactation depend on maternal nutrition status. Therefore, the food consumed by mother must be contained of high nutrition in order to produce high quality of milk. Irawati et al. [10] proposed that successful of breastfeeding depended on nutrition status of maternal during lactation, after food pattern and social economic factors were controlled. The result showed that mother who had Body Mass Index (BMI) $<18.5$ experienced unsuccessful breastfeeding during lactation with RR 2.26-2.56 times. Meanwhile, mothers with normal BMI (>18.5-25.0) had successful breastfeeding. Thus, mother should consume more high nutrition food to achieve successful breastfeeding [10].
Budiman [23] showed that lack of nutritional intake reduces the quality of the milk produced affecting the baby's nutritional and weight. Budiman [23] in his study about mothers' delivery in Garuda's birth health centre in Cimahi Bandung Indonesia described that there was a relationship between the status of mothers' nutrition and neonatal' health. He said that 34 mothers (8.3\%) out of 408 delivered in health centre had deficiency of nutrition. As a result these babies were born with low birth weight. Consequently, mother with insufficient nutritional intake can suffer from anaemia leading to decrease the transport of oxygen and nutrient to the foetus. Hani [24] stated that poor nutritional status before and during pregnancy were a major cause of a variety of serious health problems in mothers and babies such as low birth weight (LBW), preterm labor and increased prenatal and neonatal mortality. WHO (2010) reported that maternal malnutrition was one of the biggest factors for infant mortality. The infant defense mechanism system will decline due to the low quality of mother's milk. As a consequence the infant will vulnerable to various infectious diseases $[16,17]$. In this study one of the participants said that she gave food supplement to her child aged 2 months because the baby continues to cry, despite of being breast-fed as a result of the postpartum mother only consuming rice porridge for 40 days.

Finding the solution to this problem is one of the greatest challenges faced by the health worker because pregnant and postpartum women are prohibited to consume fish. They believed that breast milk would smell fishy if they eat fish. Research conducted by Prawirohardjo [25] said that $50 \%$ incidence of infant death mostly occur during neonatal period, especially first 7 days of life. Nursing or mother intervention to prevent any problems that lead to physical defect or death is really important in this time. Unfortunately, in some cultural groups in NTT, new mothers and the babies are forbidden to leave the house for 40 days after delivering. In fact, a baby needs some neonatal care such as immunization, cord care, and physical examination [1]. Provincial Health Office in his technical direction to sharply decrease of infant mortality rate stated that health care workers should have visited neonates at least 3 times. First visitation is carried out in 6 to $48 \mathrm{~h}$ after birth; second is 3 to 7 days and last visitation is 8 to 28 days $[1,6]$. The first neonatal visitation is the scope of new-born health care age 6 to 48 h. in certain area and time respectively. The training health care worker should have applied the standard of care in entire health care facilities. Health care are taken during neonatal visitation including examination that met the standard of Integrated management of new-born and counselling of new-born care including exclusive breast feeding and cord care.

Notoatmodjo [26] stated that pregnant women' knowledge can be gained from the experience themselves and others without any proof first. This belief can affect the mother's knowledge both positively and negatively. Knowledge is an important component of predisposing factors. Despite more knowledge does not necessarily lead to changes in behaviour but have a positive relationship, in which the increased knowledge will make the behavioural change more quickly. So a good knowledge about the examination of the new-born or neonatal form of physical exam, immunization, clean cord care, should inform the danger signs in neonates. This will give an understanding of the importance of neonatal and subsequently visit will develop a positive attitude about the visit and creating a new behaviour in regard regular neonatal visit. 


\section{Conclusion}

This research sets three themes to be discussed. The first theme of the visit for a check-up New-born baby; the second theme is the quality of milk and the last theme is level of mother knowledge. The conclusion is that mother's experience in caring for babies aged 0-7 days based on behavioural patterns inherited or taught by parents or ancestors. They clung to the doctrine that prohibit them to go out from the house for 40 days post birth; forbidden to eat fish during pregnancy and childbirth. As a result neonatal visit was not done not only by mother but also by health worker. Mothers and families do not have guidance and counselling about infant care because they do not visit health facilities and they are also not visited by health workers according to the program of decreasing neonatal mortality [6]. As a result, families and mothers care for their babies with a derivative of the standard family or in other words not fit the standard new-born care. All these conditions are the reason why morbidity and infant mortality in NTT Province are still high today. Further study should be done by Provincial and District Health Office to motivate the mother and family to be faithful to government regulation standard to take care of neonatal. Midwife and nurse should provide health education about the benefit of neonatal visitation regularly and continuously.

\section{Recommendation}

The government in this case the Provincial and District Health Office and its staffs are expected to disseminate the policy on reducing infant mortality leap constantly to the public.

Health workers are highly encouraged to carry out home visit in families with new-born 0 to 7 days for 3 times according to standards set by the government and provide health education on a regular basis to the public, particularly in couples of child bearing age and pregnant women. They are expected to design the guidelines and counselling regarding to decrease infant mortality rate to the community through education started at prenatal period.

Head of the village are expected to insist the community especially post-natal women to visit health facility at least 3 times for neonates.

Families who have a new-born baby are expected to check up their baby to a medical facility at time suitable for them when not visited by a health worker.

\section{References}

1. Kementerian Kesehatan, (2015)Profil Kesehatan Indonesia, Jakarta

2. Ministry of Health: Badan Litbang Depkes (2007) Laporan Nasional Riskesdas, Jakarta.

3. Kesehatan D (2014) Profil Kesehatan Provinsi NTT. Kupang.

4. Kesehatan D (2015) Profil Kesehatan Provinsi NTT, Kupang.
5. Katalog Dalam Terbitan (2014) Profil Kesehatan Indonesia, Jakarta.

6. Kesehatan D Provinsi Nusa Tenggara Timur (2015) Petunjuk Teknis Lompatan Penurunan Kematian Bayi di Provinsi NTT, Kupang.

7. Zuraida (2016) Faktor-Faktor Yang Berhubungan Dengan Kunjungan Neonatus Di Wilayah Kerja Puskesmas Lubuk Kilangan, Jurnal Human Care.

8. Darmawan HF, Dewi MJ (2011) Hubungan Pengetahuan Ibu dan Dukungan Suami dengan Kunjungan Neonatus 1 (KN 1) di Wilayah Kerja Puskesmas Pasirlangu Kabupaten Bandung Barat, Bandung.

9. Mahmudah U, Cahyati HW, Wahyuningsih SA (2011) Analisis Faktor Ibu dan Bayi yang Berhubungan dengan Kejadian Kematian Perinatal, Jurnal Kesehatan Masyarakat 7:46-56.

10. Irawati A, Triwinarti A, Salimar, Raswanti I (2003) Pengaruh Status Gizi Ibu Selama Kehamilan dan Menyusui Terhadap Keberhasilan Pemberian Air Susu Ibu, Jurnal Penelitian Gizi dan Makanan 26: 10-19.

11. Esterberg, Kristin G (2002) Qualitative Method in Social Research, Mc Graw Hill, New York.

12. Cresswell JW (2013) Qualitative Inquiry Research Design: Choosing Among Five Approaches. Thousand Oaks: Sage.

13. World Health Organization South East Asia Region, (2001), Making Pregnancy Safer a Health Sector for Reducing Maternal and Perinatal Morbidity and Mortality.

14. Raharni, Iskakh BM, Diana I (2011) Profil Kematian Neonatal Berdasarkan Sosio Demografi dan Kondisi Ibu Saat Hamil di Indonesia, Buletin Kesehatan 14: 291-398.

15. Badan Pusat Statistik (2008) Survei Demografi dan Kesehatan Indonesia 2007. Macro, Calverton, Maryland, USA.

16. Pedoman Teknis Pelayanan Kesehatan Dasar (2010) Buku Saku: Pelayanan Kesehatan Neonatal Esensial, Jakarta.

17. Kementerian Kesehatan RI \& IDAI (2011) Manajemen Terpadu Balita Sakit (MTBS), Jakarta.

18. World Health Organization (2003) Promoting Effective Perinatal Care: Essential Newborn Care and Breastfeeding Training modules.

19. Kesehatan D (2009) Pedoman Percepatan Penurunan Kematian Ibu dan Bayi Baru Lahir. KupNg

20. Bang AT, Bang RA, Reddy HM, Deshmukh MD, Baitule SB (2005) Reduce Incidence of Neonatal Morbidities: Effect of Home-Based Neonatal Care in Rural Gadchiroli, India. J Perinatol 25: SS1-S61.

21. Karim AM, Admassu K, Schellenberg J, Alemu H, Getachew N, et al. (2013) Effect of Ethiopia's Health Extension Program on Maternal and Newborn Health Care Practices in 101 Rural Districts: A Dose-Response Study, PLoS One 6: e65160.

22. Kesehatan RI (2004) Permenkes Nomor 50/2004 tentang ASI Eksklusif. Jakarta.

23. Budiman Dkk (2010) Faktor Ibu yang Berhubungan dengan Berat Badan Bayi Lahir di Puskesmas Garuda Tahun, Jurnal Kesehatan Kartika.

24. Hani U (2010) Asuhan Kebidanan Pada Kehamilan Fisiologis, Jakarta: Salemba Medika.

25. Prawirohardjo (2006) Ilmu Kebidanan edisi 3. Tridasa Printer, Jakarta

26. Saputra W, Fanggidae V, Maftuchan Ah (2013) Efektifitas Kebijakan Daerah Dalam Penurunan Angka Kematian Ibu dan Bayi, Jurnal Kesehatan Masyarakat Nasional 7: 531-537. 